\title{
Analisis Risiko Asupan Oral Pajanan Mangan dalam Air terhadap Kesehatan Masyarakat
}

\author{
Taufik Ashar*
}

\begin{abstract}
Abstrak
Mangan yang secara alami dapat ditemukan di air, tanah, dan udara adalah zat nutrisi esensial bagi manusia dan hewan. Asupan yang tidak mencukupi atau yang berlebihan dapat gangguan kesehatan. Pajanan kronik mangan pada dosis yang tinggi dapat mengakibatkan gangguan pada sistem saraf. Tujuan penelitian ini adalah mengetahui perkiraan risiko kesehatan akibat asupan mangan dari air sumur di wilayah penelitian. Penelitian dengan disain crossectional ini dilakukan terhadap masyarakat di wilayah sekitar TPA Rawakucing yang meliputi masyarakat yang bermukim di dalam kawasan (114 orang), dan di luar kawasan TPA (177 orang). Hasil penelitian menunjukkan rata-rata konsentrasi mangan dalam air sumur di wilayah sekitar TPA Rawakucing (4.3 mg/l ; $\mathrm{SD}=2.8873 \mathrm{mg} / \mathrm{l})$. Berbeda sevara bermakna debgan di luar TPA Rawakucing (0.300 mg/l; SD=0.1888 mg/l). (nilai $p<0.05)$. Rata-rata besaran risiko (RQ) gangguan kesehatan akibat mengkonsumsi air yang mengandung mangan pada masyarakat yang tinggal di TPA Rawakucing (0.2347) dan yang tinggal di luar TPA Rawakucing (0.2955). Masyarakat yang tinggal di TPA berisiko gangguan kesehatan 8,12 kali lebih bedsar daripada yang tinggal di luar TPA ( $<<0.05$ ) dengan $\mathrm{OR}=8.109(95 \% \mathrm{Cl}=2.668-24.650)$.
\end{abstract}

Kata kunci : Mangan, TPA, analisis risiko kesehatan, tingkat risiko

\begin{abstract}
Manganese that can be found ubiquitously in the air, soil, and water is an essential nutrient for humans and animals. Inadequate intake or over exposure can cause adverse health effects. Although manganese is an essential nutrient at low doses, chronic exposure to high doses may be harmful. Regardless, the nervous system has been determined to be the primary target organ with neurological effects generally observed. The objective of the study is to assess the health risk of manganese exposure from the well drinking water intake. This study was done in Final Disposal Site Rawakucing area and outside of this area . The number of subjects were 114 who lived inside the site and 177 who lived outside the area, respectively. Study design is cross-sectional with hypotheses testing. The result showed that the average manganese concentration was $4.3 \mathrm{mg} / \mathrm{l}(\mathrm{SD}=2.8873), 0.300 \mathrm{mg} / \mathrm{l}(\mathrm{SD}=0.1888)$ respectively. The result was significant different statistically $(p<0.05)$ for manganese concentration from two study area. The average $R Q$ showed $0.2347(S D=0.5095)$ for $R Q$ in $D$ isposal Site Area and $0.2955(S D=0.2465)$ for $R Q$ outside Disposal Site Area. The result was statistically significantly different $(p<0.05)$ for $R Q$ value, with $O R=8.109$ $(95 \% \mathrm{Cl}=2.668-24.650)$.
\end{abstract}

Keywords : Manganese, disposal site area, health risk assessment, risk quetient 
Mangan yang secara alami banyak ditemukan di udara, air, dan tanah merupakan unsur esensial bagi manusia dan hewan.1,2 Konsumsi yang kurang atau berlebihan dapat berdampak buruk pada kesehatan manusia terutama yang terpapar mangan dari makanan. Meskipun mangan merupakan salah satu unsur esensial bagi manusia dan hewan, tetapi paparan kronis sampai pada dosis yang tinggi dapat membahayakan kesehatan dengan target adalah sistem saraf. Suatu studi epidemiologi yang dilakukan di Yunani ${ }^{3}$ menunjukkan bahwa konsumsi air minum yang secara alami mengandung konsentrasi mangan yang cukup tinggi seumur hidup, berisiko menimbulkan gejala-gejala neurologi dan peningkatan retensi mangan. Hal tersebut ditandai oleh konsentrasi mangan yang tinggi dalam rambut penduduk berusia di atas 50 tahun.

Suatu komunitas kecil di Jepang yang terdiri dari 25 orang mengkonsumsi air minum dari sumur yang tercemar mangan konsentrasi tinggi dari sumber pencemaran sel-sel baterai kering yang dikubur tidak jauh dari sumur penduduk. Setelah mengkonsumsi air yang terkontaminasi tersebut selama sekitar 3 bulan mereka mengalami kelainan neurologis dengan gejala-gejala yang meliputi dalah letargi, peningkatan tonus otot, tremor, gangguan mental, dan bahkan kematian. Perkiraan konsentrasi mangan hampir mencapai $29 \mathrm{mg} / \mathrm{L} \mathrm{(58} \mathrm{mg/hari} \mathrm{atau} \mathrm{se-}$ kitar $1 \mathrm{mg} / \mathrm{kg}$-hari dengan asumsi berat badan $60 \mathrm{~kg}$ ). ${ }^{4}$ Suatu studi karakteristik leachate yang dilakukan di Onnuch, sebuah kawasan tempat pembuangan sampah dengan sistem open dumping di Bangkok Thailand menemukan konsentrasi mangan sekitar 0,01 - 2,88 ppm. ${ }^{5}$

Dinas Kesehatan Kota Tangerang, ${ }^{6}$ melakukan pengambilan sampel terhadap seluruh sumur penduduk di sekitar TPA Rawakucing. Dari hasil pemeriksaan parameter kimia, seluruh sumur menunjukkan konsentrasi mangan berada di atas kadar maksimum yang diperbolehkan berdasarkan Peraturan Menteri Kesehatan Republik Indonesia No. 416/MENKES/ SK/IX/90 tentang Persyaratan Kualitas Air Bersih yaitu $0,5 \mathrm{mg} / \mathrm{L}$. Konsentrasi mangan terendah adalah 1,61 $\mathrm{mg} / \mathrm{L}$ dan konsentrasi tertinggi 13,95 mg/L. Masyarakat di kawasan TPA Rawakucing kecamatan Neglasari kota Tangerang Propinsi Banten sangat rentan terhadap terjadinya gangguan kesehatan akibat tingginya konsentrasi mangan pada air sumur mereka yang jauh melebihi kadar maksimum yang diperbolehkan. Berdasarkan hal tersebut maka penelitian ini melakukan analisis risiko dampak mangan dalam air sumur terhadap kesehatan masyarakat di kawasan TPA Rawakucing.

Tujuan Penelitian ini adalah menganalisa besar risiko gangguan kesehatan masyarakat di sekitar TPA Rawakucing kecamatan Neglasari Kota Tangerang Propinsi Banten terhadap efek non-karsinogen mangan akibat mengkonsumsi air dari sumur yang mengandung mangan pada tahun 2007.

\section{Metode}

Penelitian yang menggunakan desain kross sektional ini membandingkan masyarakat yang bermukim di dalam lingkungan TPA Rawakucing, RT 04 RW 04 kelurahan Kedaung Wetan dan di luar lingkungan RT 02 RW 02 kelurahan Kedaung Baru. Analisis konsentrasi logam mangan dalam air sumur dilakukan di Laboratorium Departemen Kesehatan Lingkungan Fakultas Kesehatan Masyarakat Universitas Indonesia (FKM UI), Depok. Penelitian dilaksanakan pada periode April - Juni 2007. Populasi adalah seluruh masyarakat yang tinggal di TPA dan di luar TPA Rawakucing yang masih berdekatan dengan kawasan TPA Rawakucing di kecamatan Neglasari kota Tangerang Propinsi Banten pada tahun 2007. Populasi obyek adalah seluruh sumur yang ada di TPA dan di luar TPA Rawakucing yang masih berdekatan dengan kawasan TPA Rawakucing di kecamatan Neglasari Kota Tangerang Propinsi Banten pada tahun 2007.

Sampel dalam penelitian ini adalah masyarakat berusia $\geq 18$ tahun yang tinggal di TPA dan di luar TPA Rawakucing dan telah bermukim selama minimal 2 bulan. Hal tersebut dilakukan atas pertimbangan hasil penelitian bahwa gejala-gejala gangguan saraf muncul setelah terpajan mangan dalam air minum dalam kurun waktu 2-3 bulan. ${ }^{4}$ Unit analisis adalah individu yang mengkonsumsi air yang berasal dari sumur yang berada di lingkungan komplek TPA Rawakucing. Sampel sumur yang akan diambil adalah sumur yang airnya dikonsumsi untuk keperluan sehari-hari masyarakat di TPA dan di luar TPA Rawakucing kecamatan Neglasari kota Tangerang propinsi Banten tahun 2007. Jumlah sampel adalah 114 orang untuk kelompok subyek di TPA dan 177 orang untuk kelompok subyek di luar TPA yang tersebar 98 orang di RT 04 RW 04 kelurahan Kedaung Wetan dan 79 orang di RT 02 RW 02 kelurahan Kedaung Baru. Jumlah sampel sumur adalah 27 titik sampel sumur, yang meliputi tujuh sumur di TPA Rawakucing dan 20 sumur di luar TPA dengan perincian masing-masing sepuluh sampel air sumur dari RT 04 RW 04 kelurahan Kedaung Wetan dan sepuluh sampel air sumur dari RT 02 RW 02 kelurahan Kedaung Baru.

Pengolahan data menggunakan perhitungan analisis risiko dengan cara menghitung asupan (intake), untuk mengetahui tingkat risiko risk agent (RQ) terhadap konsumen. Data asupan konsentrasi mangan dalam air minum diperoleh dengan menggunakan persamaan berikut. ${ }^{7}$

$$
I=\frac{C \times R \times f_{e} \times D_{t}}{W_{\mathrm{b}} \times t_{\mathrm{avg}}}
$$


Untuk mengetahui tingkat risiko kesehatan yang akan terjadi pada setiap individu, dilakukan perhitungan RQ dengan menggunakan persamaan berikut:

$$
\text { Risk Quotients }(\mathrm{RQ})=\frac{\text { Intake }(\mathrm{mg} / \mathrm{kg}-\text { hari })}{(\mathrm{RfD}=0,047 \mathrm{mg} / \mathrm{kg}-\text { hari })}
$$

Hasil perhitungan RQ dapat menunjukkan tingkat risiko kesehatan masyarakat akibat mengkonsumsi air minum yang mengandung mangan. Apabila $R Q<1$ menunjukkan pajanan masih berada di bawah batas normal dan penduduk yang mengkonsumsi air tersebut aman dari risiko kesehatan oleh mangan sepanjang hidupnya. Sedangkan, bila RQ $>1$ menunjukkan pajanan berada di atas batas normal dan penduduk yang mengkonsumsi air tersebut memiliki risiko kesehatan oleh mangan sepanjang hidupnya. Dalam penelitian ini uji yang digunakan uji chi-square karena variabel independen dan variabel dependen termasuk variabel kovariat merupakan data kategorik (data numerik yang sudah diubah menjadi dua kelompok). Uji ini digunakan untuk menilai perbedaan proporsi dua kelompok sampel.

\section{Hasil}

\section{Konsentrasi Mangan dalam Air Sumur}

Pemeriksaan terhadap 27 titik sumur di lokasi penelitian menemukan perbedaan konsentrasi mangan antara sumur di TPA dan di luar TPA yang bermakna. Rata-rata (mean) konsentrasi mangan ketujuh air sumur di TPA adalah 4,3 mg/l, sedangkan rata-rata (median) ke-20 air sumur di luar TPA Rawakucing adalah 0,300 mg/l. (Lihat Tabel 1)

\section{Laju Asupan Konsumsi Air yang Mengandung Mangan}

Rata-rata (median) laju asupan konsumsi air di loka- si penelitian adalah 2,0833 1/hari. Laju asupan konsumsi air di lokasi penelitian ini tidak jauh berbeda dengan anjuran kesehatan dalam hal pola minum dengan meminum sekurangnya 2 liter air per hari. Dari hasil uji beda ditemukan perbedaan proporsi besar risiko gangguan kesehatan antara responden yang mengkonsumsi air yang melebihi 2 liter per hari dengan responden yang mengkonsumsi air yang tidak melebihi 2 liter per hari dengan nilai OR 4,740. Responden yang mengkonsumsi air $\geq 2$ liter per hari berisiko 4,740 kali lebih besar untuk mengalami gangguan kesehatan daripada responden yang mengkonsumsi air $<2$ liter per hari.

\section{Durasi Pajanan}

Rata-rata (median) durasi pajanan di lokasi penelitian adalah 19 tahun dengan durasi pajanan terendah adalah 0,33 tahun (4 bulan) dan terlama 80 tahun. Dari 291 responden yang diteliti, sekitar 47,1\% (137 orang) telah terpajan mangan selama lebih dari 19 tahun. Dari uji statistik diperoleh nilai OR 0,227, sehingga disimpulkan bahwa responden yang mengkonsumsi air yang mengandung mangan lebih dari 19 tahun berisiko 0,227 kali lebih besar untuk mengalami gangguan kesehatan atau konsumsi selama lebih dari 19 tahun akan melindungi repsonden sebanyak 4,41 kali.

\section{Berat Badan}

Dalam analisis risiko, berat badan akan mempengaruhi besarnya nilai risiko dan secara teoritis semakin berat badan seseorang maka semakin kecil kemungkinannya untuk berisiko mengalami gangguan kesehatan. Dalam penelitian ini, dari hasil uji bivariat diperoleh nilai $\mathrm{p}=0,186$ dan nilai interval kepercayaan yang mencakup nilai $1(0,179-1,245)$, sehingga disimpulkan tidak ada perbedaan proporsi besar risiko gangguan kesehatan antara responden yang memiliki berat badan lebih dari

Tabel 1. Statistik Diskriptif Konsentrasi Mangan (mg/l) dalam Air Sumur menurut Tempat Tinggal

\begin{tabular}{llcccc}
\hline Tempat Tinggal & N & Mean / Median & Min / Maks & SD & p-value \\
\hline TPA & 7 & $4,3 / 5,7$ & $0,3 / 7,7$ & 2,8873 & 0,177 \\
Luar TPA & 20 & $0,375 / 0,300$ & $0,2 / 0,8$ & 0,1888 & 0,010
\end{tabular}

Tabel 2. Analisis Bivariat Faktor Determinan Gangguan Kesmas

\begin{tabular}{lllll}
\hline Variabel & Katagori & P value & OR & 95 \% CI OR \\
\hline Konsentrasi Mangan & $>05 \mathrm{mg} / \mathrm{l}$ & 0,000 & 31,03 & $4,15-236,19$ \\
Laju Asupan Konsumsi air (mg/ l) & $>21 /$ hari & 0.006 & 4,74 & $1,56-14,37$ \\
Durasi pajanan (tahun) & $>19$ tahun & 0,009 & 0,227 & $0,07-0,69$ \\
Berat Badan (Kg0 & $>50 \mathrm{mg}$ & 0,186 & 0,473 & $0,19-1,245$ \\
Tempat Tinggal & TPA & 0,000 & 0,109 & $2,67-24,65$
\end{tabular}


$50 \mathrm{~kg}$ dengan responden yang memiliki berat badan kurang dari atau sama dengan $50 \mathrm{~kg}$. Tentu saja, ini bertentangan dengan teori yang ada. Seharusnya sesuai dengan perhitungan matematis besar RQ akan berbanding terbalik dengan berat badan, artinya semakin kecil berat badan seseorang maka besar risiko $(\mathrm{RQ})$ individu tersebut akan semakin besar.

\section{Besar Risiko}

Penelitian ini menghasilkan 291 nilai RQ. Dari dua kelompok lokasi yang diteliti yaitu kelompok populasi di TPA dan kelompok populasi yang bermukim di luar TPA, yang memiliki RQ $>1$ terdapat sebanyak 22 responden atau sebanyak 7,6\% dari seluruh responden yang diperiksa. Dan dari 22 responden yang memiliki RQ $>1$ terdapat 18 responden $(81,8 \%)$ bermukim di TPA. Dengan nilai OR 8,109, dapat diambil kesimpulan bahwa responden yang tinggal di TPA Rawakucing mempunyai peluang 8,109 kali memiliki risiko akan mengalami gangguan kesehatan akibat mengkonsumsi mangan yang terkandung dalam air dibandingkan dengan responden yang tinggal di luar TPA Rawakucing.

Rata-rata (median) besaran risiko di lokasi penelitian adalah 0,2796. Hasil ini menunjukkan bahwa masyarakat di lokasi penelitian berdasarkan parameter populasi belum memiliki risiko akan terkena gangguan kesehatan akibat mengkonsumsi mangan dari air sumur yang ada di lokasi penelitian. Namun demikian, bila dikelompokkan berdasarkan pajanan mangan dari air sumur, maka terdapat 129 orang $(44,3 \%)$ di lokasi penelitian yang terpajan mangan pada konsentrasi yang melebihi kadar yang diperbolehkan dan yang memiliki risiko akan terkena gangguan kesehatan akibat mangan ada sebanyak 21 responden $(16,3 \%)$. Sementara itu hanya ada 1 responden yang memiliki RQ $>1$ yang mengkonsumsi mangan di bawah kadar yang diperbolehkan.

\section{Pembahasan}

Peraturan Menteri Kesehatan Republik Indonesia No. 416/MENKES/SK/IX/90 tentang Persyaratan kualitas Air Bersih menyebutkan bahwa konsentrasi mangan maksimal adalah 0,5 mg/l. Berdasarkan Permenkes ini, maka dari tujuh titik sumur yang ada di TPA, hanya satu sumur yang konsentrasi mangannya masih di bawah kadar maksimal yang diperbolehkan, sedangkan selebihnya konsentrasi mangannya melebihi kadar yang diperbolehkan dengan konsentrasi tertinggi mencapai 7,7 $\mathrm{mg} / \mathrm{l}$. Sebagai perbandingan, untuk konsentrasi mangan dari 20 titik sumur yang diperiksa di luar TPA Rawakucing hanya 3 titik sumur yang konsentrasi mangannya melebihi kadar maksimal yang diperbolehkan, dengan konsentrasi tertinggi adalah $0,8 \mathrm{mg} / \mathrm{l}$. Secara total keseluruhan maka terdapat enam titik sumur di lokasi penelitian yang tidak memenuhi syarat un- tuk konsentrasi mangan.

Berdasarkan penilaian populasi, laju asupan air yang tidak melebihi 2 liter/hari, masih tergolong aman untuk dikonsumsi, tapi secara individu besar risiko (RQ) gangguan kesehatannya berbeda karena variabilitas faktor risiko ditentukan juga oleh karakteristik antropometri dan pola pajanan. Dengan mensubstitusikan nilai-nilai yang diperoleh dari penelitian maka diperoleh nilai ratarata (median) asupan adalah $0,013 \mathrm{mg} / \mathrm{hari}$. Apabila diambil nilai rata-rata berat badan populasi penelitian adalah $50 \mathrm{~kg}$, maka asupan mangan yang diperoleh dari air minum di lokasi penelitian adalah $0,65 \mathrm{mg} / \mathrm{hari}$. Jika dibandingkan dengan kisaran asupan yang masih aman dan adekuat untuk orang dewasa menurut Badan Gizi dan Makanan USA (2-5 mg/hari) atau kisaran yang direkomendasikan Komite Sains Uni-Eropa (1-10 mg/hari), maka asupan mangan pada populasi di wilayah penelitian melalui air minum tentu saja masih kurang. Namun, penelitian ini tidak melakukan perhitungan asupan mangan dari sumber lain, sehingga belum dapat ditentukan apakah populasi yang diteliti mengalami defisiensi mangan atau tidak.

Durasi pajanan yg ditemukan bertolak belakang dengan hasil-hasil penelitian yang pernah dilakukan. Kaitannya dengan hasil penelitian ini adalah karena distribusi responden yang terpajan mangan yang lebih dari 19 tahun dan memiliki RQ $>1$ hanya 2,9\%, sehingga distribusi durasi pajanan terpusat pada kelompok responden yang terpajan mangan lebih dari 19 tahun yaitu sebanyak $97,1 \%$. Dengan kata lain, variabel durasi pajanan dalam penelitian ini tidak merupakan data yang baik untuk dianalisis karena memiliki sebaran data yang homogen, sehingga hasil analisis tidak menggambarkan atau tidak sesuai dengan teori yang ada.

Pajanan yang terus menerus dari mangan dapat mengakibatkan gangguan kesehatan. Target organ yang sering terganggu adalah sistem saraf. Sebuah studi epidemiologi yang dilakukan di Yunani meneliti kemungkinan adanya hubungan pajanan kronik (lebih dari 10 tahun) mangan dari air minum dan efek neurologi pada orangorang yang sudah tua yang berusia lebih dari 50 tahun. ${ }^{3}$ Peneliti membagi area studi menjadi 3 wilayah berdasarkan perbedaan konsentrasi mangan dalam suplai air minum. Konsentrasi mangan di wilayah A adalah 3,6-14,6 $\mu \mathrm{g} / \mathrm{L}$, wilayah B memiliki konsentrasi 81,6-252,6 $\mu \mathrm{g} / \mathrm{L}$, dan wilayah $\mathrm{C}$ memiliki konsentrasi 1.800 sampai 2.300 $\mu \mathrm{g} / \mathrm{L}$. Efek neurologi dievaluasi dengan pemeriksaan neurologi dengan mengevaluasi tingkat keparahan dari 33 gejala (seperti kelemahan/fatigue, kelainan gaya berjalan, tremor, dan distonia) dari seluruh subjek penelitian. Hasil dari pemeriksaan neurologi dinyatakan dalam bentuk skor komposite. Skor neurologi yang tinggi mengindikasikan peningkatan frekuensi dan atau semakin beratnya 33 gejala yang dievaluasi. Peneliti menunjukkan 
bahwa perbedaan skor antara wilayah $\mathrm{C}$ dan wilayah $\mathrm{A}$ secara statistik bermakna (Tes Mann-Whitney, $z=3,16$, $\mathrm{p}=0,002$ ), yang menandakan adanya gangguan neurologik pada penduduk yang tinggal di wilayah C. Dari analisis berikutnya, regresi logistik menunjukkan perbedaan yang signifikan antara wilayah A dan C ketika umur dan jenis kelamin diikut sertakan dalam analisis.

Kaitannya dengan hasil penelitian ini, dapat dijelaskan bahwa dari hasil analisa bivariat menunjukkan bahwa distribusi responden yang memiliki berat badan kurang dari $50 \mathrm{~kg}$ dan memiliki $\mathrm{RQ}>1$ hanya 9,6\% (lihat lampiran), sehingga distribusi responden cenderung terpusat pada responden dengan berat badan kurang dari atau sama dengan $50 \mathrm{~kg}$ yaitu 90,4\%. Sama halnya dengan variabel durasi pajanan, variabel berat badan dalam penelitian ini bukan merupakan variabel yang baik untuk dianalisis karena memiliki sebaran data yang homogen, sehingga hasil analisis tidak menggambarkan atau tidak sesuai dengan teori yang ada.

Jika diperhatikan hasil rata-rata nilai RQ untuk kedua lokasi penelitian, maka terlihat tidak menunjukkan perbedaan bermakna, dimana rata-rata RQ di TPA adalah 0,2347 dan di luar TPA adalah 0,2955. Seharusnya RQ populasi responden di TPA akan lebih besar daripada RQ yang dimiliki populasi di luar TPA. Hal ini disebabkan terdapat dua buah variabel yang homogen yaitu variabel durasi pajanan dan berat badan. Untuk variabel durasi pajanan, sebanyak $97,1 \%$ responden telah terpajan mangan selama lebih dari atau sama dengan 19 tahun tapi memiliki RQ kurang dari 1, sedangkan banyaknya responden yang memiliki RQ lebih dari 1 hanya 2,9\% responden. Begitu pula dengan variabel berat badan, responden yang memiliki berat badan kurang dari $50 \mathrm{~kg}$ dan memiliki RQ kurang dari 1 sebanyak 90,4\%. Sedangkan yang memiliki RQ lebih dari 1 dengan berat badan kurang dari $50 \mathrm{~kg}$ hanya 9,6\% responden.

Dari analisa hubungan konsentrasi mangan pada air sumur dengan besar risiko ( $R Q$ ) menghasilkan nilai $\mathrm{p}=$ 0,000 dan nilai interval kepercayaan yang tidak mencakup angka $1(4,149-236,191)$, sehingga dapat disimpulkan ada perbedaan bermakna proporsi besar risiko gangguan kesehatan antara responden yang mengkonsumsi air yang mengandung mangan melebihi kadar maksimal dengan responden yang mengkonsumsi air yang tidak melebihi kadar maksimal. Dengan nilai OR 31,036, dapat diambil kesimpulan bahwa responden yang mengkonsumsi air yang mengandung mangan melebihi kadar maksimal mempunyai peluang 31,036 kali memiliki risiko akan mengalami gangguan kesehatan akibat mengkonsumsi mangan yang terkandung dalam air dibandingkan dengan responden yang mengkonsumsi air yang tidak melebihi kadar maksimal. Dengan demikian, penetapan $0,5 \mathrm{mg} / \mathrm{l}$ sebagai cut off point konsentrasi maksimal mangan dalam air bersih yang diperbolehkan menu- rut Permenkes No. 416 tahun 1990 tentang persyaratan air bersih untuk parameter kadar maksimal mangan masih cukup aman untuk melindungi populasi di tempat penelitian ini dilakukan.

\section{Kesimpulan}

Berdasarkan hasil penelitian dan pembahasan yang telah dilakukan maka dapat diambil kesimpulan sebagai berikut: konsentrasi rata-rata mangan dalam air sumur di TPA Rawakucing adalah 4,3 mg/l $(\mathrm{SD}=2,8873 \mathrm{mg} / \mathrm{l})$. Sedangkan di luar TPA Rawakucing adalah 0,3000 mg/l $(\mathrm{SD}=0,1888 \mathrm{mg} / \mathrm{l})$. Rata-rata (median) laju asupan konsumsi air di lokasi penelitian adalah 2,0833 liter per hari. Rata-rata (median) durasi pajanan terhadap konsumsi air yang mengandung mangan di lokasi penelitian adalah 19 tahun. Rata-rata (median) berat badan orang di lokasi penelitian adalah $50 \mathrm{~kg}$. Besaran risiko kesehatan masyarakat akibat mengkonsumsi air yang mengandung mangan di lokasi penelitian adalah 0,2796. Proporsi masyarakat di TPA Rawakucing dan di luar TP Rawakucing kecamatan Neglasari kota Tangerang propinsi Banten pada tahun 2007, yang mempunyai besaran risiko lebih dari satu $(\mathrm{RQ}>1)$ dan mengkonsumsi mangan yang melebihi kadar yang diperbolehkan adalah 16,3\%.

Rata-rata besaran risiko ( $\mathrm{RQ}$ ) gangguan kesehatan akibat mengkonsumsi air yang mengandung mangan pada masyarakat yang tinggal di TPA Rawakucing adalah 0,2347 dan rata-rata besaran risiko (RQ) gangguan kesehatan masyarakat yang tinggal di luar TPA Rawakucing adalah 0,2955. Ada perbedaan konsentrasi mangan dalam air-air sumur yang ada di TPA dan di luar TPA Rawakucing kecamatan Neglasari kota Tangerang propinsi Banten pada tahun 2007. Ada perbedaan besar risiko gangguan kesehatan antara masyarakat yang tinggal di TPA Rawakucing dengan masayarakat yang tinggal di luar TPA Rawakucing kecamatan Neglasari kota Tangerang propinsi Banten pada tahun 2007.

\section{Saran}

Diharapkan agar Pemerintah Kota (Pemkot) Tangerang agar mempertimbangkan perubahan sistem pengelolaan TPA di Rawakucing. Salah satu alternatifnya adalah dengan menggunakan sistem sanitary landfill. Dengan sistem ini, cairan lindi tidak akan mencemari air permukaan dan air tanah di kawasan atau sekitar TPA, karena cairan lindi akan tertampung di kolam pengolah lindi. Langkah lain yang dapat dipertimbangkan oleh Pemkot Tangerang adalah dengan membuat pengolahan air komunal yang dapat menghasilkan air yang layak dan aman untuk dikonsumsi warga masyarakat di sekitar Rawakucing. Untuk Dinas Kesehatan Kota Tangerang diharapkan mampu melakukan upaya manajemen/pengelolaan risiko bagi anggota masyarakat dengan $\mathrm{RQ}>1$. Dengan melakukan manajemen risiko 
diharapkan anggota masyarakat yang memiliki risiko akan terkena gangguan kesehatan di kemudian hari akibat mengkonsumsi air yang mengandung mangan dapat terhindar.

\section{Daftar Pustaka}

1. Leach, R.M., Harris. 1997. Manganese. Clinical Nutrition in Health and Disease, 2 (Handbook of Nutritionally Essential Mineral Elements), 335-355.

2. US EPA. 2003. Health Effects Support Document for Manganese. U.S. Environmental Protection Agency, Office of Water. EPA. EPA-822-R03- 003. Washington, D.C.
3. Kondakis et al. 1989. Possible health effects of high manganese concentration in drinking water. Arch. Environ. Health 44(3):175-178.

4. Kawamura et al. 1941. Intoxication by manganese in well water. Kitasato Arch. Exp. Med. 18:145-169.

5. Soemirat, J. 1999. Kesehatan Lingkungan. Gadjah Mada University Press. Yogyakarta.

6. Pemerintahan Kota Tangerang, 2006, Pengelolaan Sampah dan Air Limbah [online], Dari: http://www:tangerangkota.go.id/ [22 Feb 2007]

7. Kolluru, R. V., Bartel \& Pitblado, R. 1996. Risk Assessment and Managemnet Handbook: for Environmental, Health, and Safety Professional, McGraw-Hill, New York. 